\section{N. Niemandt}

Prof. N. Niemandt, Head: Religion Studies, Faculty of Theology and Religion, University of Pretoria.

E-mail: nelus.

niemandt@up.ac.za.

ORCID: https://orcid. org/0000-0002-81785393

\section{Pillay}

Dr. V. Pillay, Reformed Church in Africa Charisma, Pretoria.

E-mail: vicpillay@mweb. co.za

ORCID: https://orcid. org/0000-0002-02761503

DOI: http://dx.doi. org/10.18820/23099089/ actat.Sup28.3

ISSN 1015-8758 (Print) ISSN 2309-9089 (Online)

Acta Theologica 2019

Supp 28:34-52

Date Published:

6 December 2019

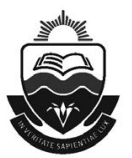

Published by the UFS http://journals.ufs.ac.za/index.php/at (๑) Creative Commons With Attribution (CC-BY) OPEN ACCESS

\section{RECONCILIATION AS A} MISSIONAL PARADIGM FOR POST-1994 SOUTH AFRICA ${ }^{1}$

\section{ABSTRACT}

The article aims to evaluate the church's role in reconciliation as a missional paradigm and attempts to find answers from biblical and theological perspectives. It discusses the issues of church, congregations, reconciliation, the Bible and people within the post-1994 South African context. There is a need to spell out the reasons for reconciliation as a paradigm for missiology in South Africa. The article addresses theological reflection, spiritual formation and empowerment, reconciliation as the praxis of the church, and faith-based reconciliation. The development of a five-point process for conflict helps in discussing the context. In developing congregations to be communities of forgiveness; being Christocentric; living in Shalom; espousing the missional approach; being open and essential communities, as well as exploring spiritual formation and empowerment will be vital for the reconciliation process. The article attempts to show how reconciliation, as the praxis for the church in South Africa, can go a considerable way to minister and meet the need of the presentday church and community. This attempt will be further supported by the development of a faithbased people and congregation to contribute to the reconciliation process. The following

1 Based on the PhD Thesis "Reconciliation, reconstruction and development as paradigms for missiology in South Africa" (Pillay 2018) 
research questions are posed: In a country that is statistically over 75 per cent Christian, why are life, actions, behaviour, morality and integrity so far removed from the Christian scriptural principles of the Bible, as the rule book and guidance for life? Why does or is the ecclesiastical Christian life not informing and impacting on life and experience in South Africa?

\section{INTRODUCTION}

South Africa reached a great achievement on 27 April 1994, with the first democratic elections. There were many reservations as to the success and outcome of these elections. On 12 September 2012, News24 reported: "The world was watching South Africa closely when the 1994 elections took place. They were waiting for violence, murder and mayhem to take place. But luckily for the South African citizens, this did not happen."

President Nelson Mandela initiated a special socio-economic policy framework called the Reconstruction and Development Programme (RDP), in order to address or redress the inequalities and injustices of the apartheid era. The key areas included housing, clean water, electrification, land reform, and healthcare. There were many reports of satisfactory progress and many reports of criticism (Corder 1997:183-203). Yet, many areas within the South African context still call for human and relational reconciliation. Crime, violence, murder, robbery, xenophobia, women and child abuse, rape, racism or racial tensions, poverty, unemployment, fraud, bribery, corruption as well as questionable community, political, and even church leadership represent areas of deep concern for unreconciled people. These present startling realities, statistics and challenges for a young democracy. The following question is raised: Should South Africa have been allowed to deteriorate to the extent in which it currently finds itself. According to Sangweni and Balia (1999:viii), as Chairperson and Chief Director of the Public Service Commission of South Africa,

(c)orruption and crime are often described as a disease or sickness of our society. In the context of understanding socially deviant behaviour, we observe that in our rapidly changing country social defects are becoming culturally patterned to such an extent that they are no longer considered contemptible or obnoxious.

The miracle of democracy in South Africa cannot be denied. A civil war was averted. The issue of reconciliation needs research, reflection and action. This present research endeavours to provide one of many answers to the issue of reconciliation. The approach is from a religious and a spiritual perspective. These perspectives will form the basis of an 
ecclesiastical missional paradigm as a dimension to meeting the need of the post-1994 South African context. The concept of faith and religion is the one common thread that weaves its way through the majority of people in South Africa. This constitutes a space for fruitful discourse on the concerns regarding reconciliation. De Gruchy states that

more than 70 percent of the people in South Africa claim membership of the Christian church. It is not surprising that the church plays an important role in the social and political life of the country (De Gruchy \& Prozesky 1990:219).

De Gruchy's statement implies that the church in South Africa is intrinsic in nature and ministry to the outcomes of lived experience in all strata of life for South African people and the country. This speaks to the impact the church could have with its influence on bringing reconciliation.

But since 1991, Christians have been particularly involved in labouring for peace and reconciliation, in monitoring and reporting violence, attending to the injuries of those who were wounded, and in seeking to bring about an atmosphere in which the politicians could seek to negotiate a solution and move on to the elections (Cassidy 1994:1).

Cassidy rightly points out that, as early as 1991, "Christians were involved in labouring for peace and reconciliation". This effort must be intensified. The church and its members in South Africa are called and challenged to this call for being the agents, facilitators, initiators and practitioners of reconciliation for the context of South Africa.

Two research questions are raised: In a country that is statistically over 75 per cent Christian, why are life, actions, behaviour, morality and integrity so far removed from the Christian scriptural principles of the Bible as the rule book and guidance for life? Why does or is the ecclesiastical Christian life not informing and impacting on life and experience in South Africa?

This research explores a few approaches to address efforts at reconciliation from theological, ecclesiastical, practical and experiential perspectives.

The use of paradigms as an approach to the theology of mission is taken from Bosch's magnus opum "Transforming missions - Paradigm shifts in theology of mission" (Bosch 1991:183-190). Although Kuhn (1996:Preface) clearly stated that the concept of paradigm was purely for the fields of study and academia in the natural sciences and not in the human sciences, Bosch (1991:368-510) successfully applied this approach to theology by mentioning a number of "emerging ecumenical missionary paradigms", but he does not address reconciliation as a possible paradigm. This current 
research follows Bosch's approach and postulates that "mission as reconciliation" is a fruitful mission paradigm in the South African context. It focuses on the following aspects:

- The introduction will spell out the reasons and need for reconciliation as a paradigm for missiology in South Africa.

- Theological reflection on reconciliation as a paradigm for missiology.

- Spiritual formation and empowerment - the impetus needed for reconciliation.

- Reconciliation as the praxis of the church in South Africa.

- Faith-based reconciliation.

\section{THE THEOLOGICAL APPROACH TO RECONCILIATION}

The biblical approach in dealing with reconciliation can be drawn from 2 Corinthians 5:11-6:2. This text refers to the concept "the ministry of reconciliation". It articulates the reconciliation of God and humankind and discusses humankind's sin and repentance as well as God's love manifested in his forgiveness to bring about this reconciliation between humankind and God. Romans 8:16 emphasises that the Holy Spirit is the author and initiator of salvation in the human heart. The question arises: Would the 70 per cent or more Christians invite this spiritual experience into their lives in order to make decisions that would emulate acts of forgiveness and reconciliation? One needs to consider the authority and interpretation of Scripture seriously in order to inform and impact on the lived experiences of everyday life in the heart of the Christian.

Kärkkäinen (2013:368) postulates that an important and vital starting point for reconciliation is the missionary proclamation of the gospel:

Salvation happens here and now. It is always in the present that God acts to heal and reconcile, thereby entering into the disruption of human lives at a great cost to himself.

In dealing with proclamation, we need to understand

salvation as an event and as a process and that the triune God who completed the work of atonement, continues to suffer for the salvation of creation (Kärkkäinen 2013:368). 
This would be an ideal juncture to address reconciliation as a paradigm for missiology in the South African context. The understanding, belief and acceptance of the theological and missional concepts of proclamation and salvation would indeed present valid, vital and intrinsic spiritual experiences to bring diverse people to the starting block.

The fact that approximately 70 per cent of South Africans attend and have links with the church supports Kärkkäinen's views of using proclamation and salvation as points of entry. This would be through the missional call to reconciliation for the South African church community. When the church talks about proclamation and salvation, it must start with the individual Christian. The conviction to change and bring reconciliation must be embedded on both sides of the divide. This calls for a rethinking, reawakening, renewing and different mindset to the old and the past. The missional and spiritual challenges for a reconciled people to a loving, caring and forgiving God must create a new heart for the recipients to engage others in the same way in which God engages them.

Volf provides an example that would help the South African church. His publication "Exclusion and embrace" (1996) brings an individual, the church and the community approach in dealing with reconciliation to face the difficult challenges of pain, suffering, murder, rape and many other violations (Volf 1996:9). The title of the book creates an interesting duel between excluding people and embracing people across the divide from where one stands. Moltman presented his lecture on this book to test Volf's conviction. The question was: "But can you embrace a četnik?". The četniks were the notorious Serbian fighters who had been torturing and persecuting the Croats and people in the country. Volf referred to them as the "ultimate other". He answered "No, I cannot - but as a follower of Christ I think I should be able to" (Volf 1996:9).

This attitude of embracing in the reconciliation process is the conviction needed in situations of grave conflict, strife, reparation, and nation-building. Volf displays both sides of human existence. The "No" answer is strongly the human response. The remainder of the answer "but as a follower of Christ" reveals the spiritual side of humanity that is obedient and willing to subject itself to Jesus as Lord. This is the battle in human reconciliation when the battle rages within oneself. The challenge for the South African Christian community is to engage with these personal battles and deal with the issues of "exclusion and embrace" as well as reconciliation, as the triune God would have it for the people and the nation.

This application to the South African context can be noted in the forgiving spirit of former President Nelson Mandela, who paved the way for 
a relatively peaceful transition of governments. In his book "The long walk to freedom", Mandela (1994:499) describes, in the chapter on "Talking with the enemy", his many conversations with those who kept him captive. He displays his strong stance for what he believed, but also the willingness to talk and reason about issues. Could these perhaps be valuable lessons for the Christian and the South African church?

There are many approaches for dealing with conflict and forgiveness. A suggested approach could be Pillay's (2018) five biblically guided steps to reconciliation: confession, repentance, forgiveness, restitution, and restoration.

- "I or we admit" - confession must be a voluntary commitment to achieve a better good. In Isaiah 1:18, God calls people to reason with $\mathrm{Him}$ and $\mathrm{He}$ would remove their sins.

- "I or we are sorry" - repentance must start with the individual or the responsible group. In Luke 5:32, Jesus said: "I have not come to call the righteous, but the sinners to repentance". This is the starting point, where there must be an apology or apologies to start the healing and reconciliation process.

- "I or we forgive" - forgiveness. In Romans 6:1, paraphrased, "can we go on sinning so that grace may increase. No! we cannot live in sin any longer". Both the Old and the New Testament highlight the theme of forgiveness. Jesus Christ is the ultimate example of forgiveness for the church and the Christian.

- "I or we will make peace" - this aspect can only become a reality and a possibility if the concepts of confession, repentance, and forgiveness have been dealt with sufficiently and adequately. In paving the way for reconciliation, the church and the Christian must initiate restitution. In Exodus 22:3, "a thief must certainly make restitution". Settling the issues of the past are crucial for the reconciliation process. The encouragement is from Philippians 4:7: "and the peace of God, which transcends all understanding, will guard your hearts and your minds in Christ Jesus". In this instance, the challenge to the church and the Christian is to reach out with genuine intention and commitment in order to deal with and implement restitution.

- "I or we will give back" - the last concept is to ensure that the vital aspect of restoration is the important action and intention at this stage. It is not easy to give back what is taken. In Leviticus 5:14-19, the guilt offering had to be given to the priest for atonement. With Jesus being 
the ultimate offering, we are encouraged and implored to act in the restoration process as was made possible by Him.

The church and the Christian can further draw from the biblical view of reconciliation in Matthew 18:15-20. In this instance, the Bible intimates a very patient and tolerant approach to confession, repentance, forgiveness, restitution, and restoration in order to facilitate and nurture the process of reconciliation. Schreiter (1998:56) explains and encourages three acts of commitment to this process,

the first is divine and human forgiveness. The second has to do with where forgiveness fits in the process of reconciliation. The third is forgiving and forgetting.

\section{SPIRITUAL FORMATION AND EMPOWERMENT - THE IMPETUS NEEDED FOR RECONCILIATION}

The argument for the spiritual approach to reconciliation as a mission paradigm is against the backdrop of the pain, suffering and mayhem experienced by humanity in our past.

The world at the end of the twentieth century is in an extraordinary state. Some would deem this to have been the most violent of all centuries known to humankind. Donald W. Scriver, Jr. reports that more than $\mathbf{1 0 0}$ million people have perished so far in wars and civil conflict (Schreiter 1998:3).

Schreiter (1992:70) repeatedly espouses that reconciliation is more of an act and part of spirituality than strategy.

Niemandt (2010:407) helps us understand the correlation between the missional call and the work of the Holy Spirit in a congregation:

The experience of the presence of God was closely related to, and overlapped with, the renewed focus on the work of the Holy Spirit.

To affirm the vital and crucial role of the Holy Spirit in the missional paradigm of reconciliation for the South African context, reference is made to an extract from the Laudium Declaration. ${ }^{2}$ The declaration is an attempt by the church to deal with the issues of apartheid, social and economic

2 The Laudium Declaration is a document put together by the Reformed Church in Africa (South Africa) at their General Synod of 1990, held at Laudium, Pretoria. 
injustices, and oppression, by addressing them by means of spiritual and ecclesiastical approaches.

\section{THE HOLY SPIRIT'S WITNESS}

We affirm that the Holy Spirit's witness to Christ is indispensable to evangelism and that without his supernatural work the new birth and the new life, evangelism is not possible and all our endeavours fruitless.

We affirm that we who proclaim the Gospel must exemplify it in a life of holiness and love, otherwise our testimony loses its credibility.

We affirm the constant need for revival and determine to seek God's face for revival in our lives, in the life of the RCA and in the church of South Africa at large.

We affirm that nothing commends the Gospel more eloquently than a transformed life and that nothing brings it into more disrepute than personal inconsistency. We determine to live worthy of the gospel of Christ (Laudium Declaration 1990).

The affirmations made in this document tug at the hearts of a people and a nation who want to work together under the guidance of the Holy Spirit. Evangelistic Witness and Compassionate Service, Unity and Prophetic Witness follow the Holy Spirit's witness. For example, Bosch transcends borders in his spiritual commitment and ministry contexts in order to reveal new understandings of spiritualities. This extends to other aspects where there is a need for reconciling (Kritzinger \& Saayman 2011:191).

The vital understanding of missional spirituality is crucial to the paradigm of reconciliation in mission for South Africa. Wright (2008:270) points out that "all spirituality should be missional spirituality". It is argued that private piety, which does not work out in actual mission, has no justification. Niemandt (2016:92) argues that missional spirituality impacts on the church to be characterised by its missional call, function and commitment. There can be no escape or avoidance for the church and the Christian in the South African context to heed the missional call and to live out and include the paradigm of reconciliation as part of its ministry and mission.

As mentioned earlier, the impetus for dealing with aspects of reconciliation for the South African church and the Christian will need the so-called "active ingredient", the work of the Holy Spirit. The two aspects of formation and empowerment are vital and necessary to enable the church and the Christian to become part of the missional paradigm 
of reconciliation within the South African context. "Since we live by the Spirit, let us keep in step with the Spirit" (Gal. 5:25). In this instance, the exhortation to the church and the Christian is to live and keep in step with the Holy Spirit. Certainly, the Spirit will guide South Africans to the truth and reality issues that need to be attended to. There is also a caution that "missional spirituality does not differ from 'normal' spirituality. All spirituality ought to be missional spirituality" (Wright 2008:270).

Although this section focuses on spiritual formation and empowerment, it has to be the experiential, practical, theological understanding and the undergirding work of the Holy Spirit in the life of the church and Christian in South Africa. Volf (1998:214) emphasises the relationship of the church and the Triune God. He goes on to discuss the dependence of the church in its ecclesiality on the Triune God. This draws us to a holistic spiritual approach, in order to address the inadequacies of bringing the missional paradigm of reconciliation in its practice and living.

Schreiter (1998:14-19) makes a case for five key points in Paul's teaching on reconciliation:

- Reconciliation is the work of God who initiates and completes in us the reconciliation through Christ.

- Reconciliation is more a spirituality than a strategy. Reconciliation as a spirituality must lead to strategy.

- The experience of reconciliation makes both the victim and the wrongdoer a new creation.

- The process of reconciliation that creates the new humanity is to be found in the story of the passion, death, and resurrection of Jesus Christ.

- The process of reconciliation will be fulfilled only with the complete consummation of the world by God in Christ.

Schreiter clearly defines a balanced scriptural, ecclesiastical and theological framework of how we could explore and implement the missional paradigm of reconciliation by emphasising being at the right place and with the right persons. Schreiter states the right place and persons is the Triune God. Bosch further encourages us when he speaks of a spirituality of the road. He refers to the Apostle Paul's spirituality as one that develops, unfolds, deepens and matures. It is a spirituality that journeys from stage to stage. Therefore, his is not a spirituality of the monastery, but of the road (Hastings 1971:84-95; Bosch 2000:20). 
Hastings and Bosch bring a soberness to the church and the Christian in South Africa, in order to deal and dialogue with the missional paradigms of reconciliation on a practical grassroots level. The basis is the spiritual formation and empowerment of how we do our ecclesiology and theology within the context of South Africa, the precinct starts from the lowest ebb.

\section{RECONCILIATION AS THE PRAXIS FOR THE CHURCH IN SOUTH AFRICA}

In dealing with praxis, a crucial aspect should be considered, namely identity. Where one finds oneself or where one positions oneself will determine much of the process and outcome of such a reconciliation endeavour. Volf talks about "the reality of otherness" (Volf 1996:16). He states that this will assist in guiding a process towards the desired goal in human relationships. Unless and until we can deal and come to terms with the vital aspect and/ or obstacle of "otherness", we may very easily lose our way or arrive at a place where there is a cul de sac with no acceptable option or solution for the process of dealing with the missional paradigm of reconciliation for South Africa.

This would call for a sincere approach to dealing with one's honesty, integrity, morality, and sincerity. The phrase "you have to bear your soul" is true for a serious and genuine attempt to address crucial matters of reconciliation. A significant approach in the praxis of implementing the missional paradigm of reconciliation would lead us to an understanding of communion. Kärkkäinen states that John Zizioloulas speaks of even God living in communion, as in the Trinity. "God's being coincides with God's communal personhood" (Kärkkäinen 2002:95-96). The church and the Christian's communion with God in the Eucharist will lead to communion with each other as the church of God. This process of an experiential communion will lead to community.

Guder (1999:21) defines the work of the church and the Christian as being the "Incarnational Communities, where the formation of the communities of faith is God's strategy for making good news known to the world". The concept and understanding of mission incarnationally bring an important dimension in the witness of the church and the Christian. This means that, when communion and incarnational witness are combined, the logical result would be mission communities or communities of mission.

For the South African context, the start of these communities would be "communities of forgiveness". The monumental work of Father Michael Lapsley (2002:2) speaks to the Truth and Reconciliation Commission 
and the biblical basis for forgiveness, healing and recovery. This helps the formation of the "communities of forgiveness". Hastings (2012:121) explores a few more communities that would enhance the healing processes in helping to facilitate the missional paradigm of reconciliation. Hastings defines these communities as:

- The church as "Christocentric communities" (2012:122) - the church being the Christ-centred community that draws from their relationship in the centrality of Christ to become the community that can cope and deal with the planning and praxis of addressing the reconciliation processes in the South African context.

- The church is called to be the "the communities of shalom" (2012:126) - the church is the initiator and bearer of the shalom, peace. This peace must become the ministry of the church and the Christian in all and every aspect of life and living.

- The church as "missional, open communities" (2012:128) - the church takes on the role of hospitality, as in caring, pastoral, healing, feeding, providing and ministering with its spiritual attributes.

- The church is the "essential communities" (2012:131) - the church is essential and definitive of Christian salvation and life.

Being these communities and other communities as may be defined by various theologians, the church would go a long way to bring the reality and experience of the gospel of salvation. The results that follow would help deal with the attributes of the missional paradigm of reconciliation by the church and the Christian for the South African context.

In order not to be distant from reality and only focus on the spiritual and religious aspects of reconciliation for a specific situation and, in this case, South Africa, we need to have some guidance of what this may be. We need to list the basic principles of the Reconstruction and Development Programme (RDP): an integrated and sustainable programme; a peopledriven process; peace and security for all; nation-building; link construction and development; democratisation of South Africa.

These basic principles of the RDP would certainly assist in keeping the academic and theological discourse on the ground. There are many utopian and idealistic approaches of dealing with reconciliation but, being so far-fetched, it never reaches its intended destination, situation or people. It is important to always focus on what needs to be achieved in meeting the demands. 
For the church to meet the demands and requirements of the RDP, there must be a few approaches to the reconciliation issue. Bevans and Schroeder (2004:389) provide some options by intimating that reconciliation can take place at different levels. The church needs to be involved on all these levels. The latter must be guided and informed by spiritual empowerment and formation, theological discourse, and scriptural substantiations.

The first level would be the personal level of reconciliation. Personal reconciliation must become a personal responsibility. This directly impacts on the Christian. Christians cannot be bystanders in addressing areas, situations, problems, issues and challenges that affect people and communities (Bevans \& Schroeder 2004:391).

The second level would be cultural reconciliation. In this instance, the need is to transcend the boundaries of culture and tradition. This area is not so easy to deal with, because many people are deeply rooted and entrenched in their cultures and traditions. Reconciliation at this level needs a great deal of patience, time, and consideration. Intense levels of commitment are needed to navigate a way through this level of reconciliation for the people, community and the country as may be required by the South African context (Bevans \& Schroeder 2004:391).

The third level is political reconciliation (Bevans \& Schroeder 2004:391). The need at this level is to find national initiatives such as the Truth and Reconciliation Commission of South Africa (TRC). The TRC served a cause and met some needs towards reconciliation. Sachs (2001:99), a constitutional court judge, points out the role of the TRC as "humanising" South Africa. Despite her many criticisms of the TRC, Jardine (2008:1) maintains that the policy of amnesty was a crucial aspect in balancing the past with that of the future. All of this may bring desired results for reconciliation as a missional paradigm in South Africa. In the title of his book "The end of memory - Remember rightly in a violent world", Volf (2006) reminds us of a call to end memory and to remember rightly. All of this requires the experience of pain and suffering through physical, emotional, mental and psychological violence. He goes on to discuss more elaborately what could be an imagined reconciliation (Volf 2006:215). The imagined and expected reconciliation could be mind games of what the real need and practice of a reconciled people and nation should and must be.

The fourth level is the essential community. The church and its membership are essential and definitive of salvation and life. As the Christian community grows to become the essential community, its role would greatly and intrinsically feed into this process. The church and the Christian community need to be encouraged to view, believe and start working 
towards becoming the essential community. All these communities must lead the South African Christian and churches, as people and institutions of change, to facilitate the missional paradigm of reconciliation. They can turn to a "faith-based reconciliation" as the vehicle on which it could journey (Bevans \& Schroeder 2004:392).

\section{FAITH-BASED RECONCILIATION}

Cox (2007) articulated eight core values for faith-based reconciliation. ${ }^{3}$ These values represent an important contribution and basis for developing a praxis for the church in responding to a missional paradigm for reconciliation (Pillay 2018:270).

\subsection{Pluralism}

Pluralism means that we seek unity in diversity. In this instance, the existential reality will be measured against a principle or core value. The ethnic and cultural diversity is a gift from God and part of the richness of human experience. This would mean that we show respect for the distinctive while we focus on the basis for common ground.

The Christian perspective on pluralism: Jesus' choice of disciples was a model of an intentional pluralistic community: (Simon the Zealot and Matthew the tax collector). The church in Antioch was the model of an intentional multicultural, Jewish/Gentile faith community.

\subsection{Inclusion}

Compassionate inclusion means that we seek to overcome hostility by practising unconditional love towards others, including one's enemies. It involves distinct moral choices on how we relate to "the other". The requirement would be our willingness to confront our own hostility towards "the other". In confronting people and groups who are different from ourselves in terms of ethnicity, class, culture, religion or political ideology, there are three basic attitudes that involve distinct moral justices: exclusion, tolerance, and inclusion. Exclusion means driving "the other" from our midst by means of social ostracism, economic injustice or ethnic cleansing. Tolerance is a veiled form of indifference and means "putting

3 Cox's paradigm is informed by his active involvement in politics, theological training, being an Anglican pastor, professionally trained conflict mediator, an adjunct Professor at Pepperdine University Law School in Malibu, California, and seventeen years of faith-based reconciliation work in East Central Europe, Kashmir, Sudan, and the Middle East. 
up" with the other, even when in our hearts, their presence is an irritation or imposition. Inclusion or embrace is based on agape or unconditional love.

The Christian perspective on inclusion: The radical elevation of unconditional love as a socio-political principle may have been unique in Jesus' message. Jesus repudiated barriers of gender, tribe, religion, class, caste and ideology in establishing a social practice of inclusivity.

\subsection{Peace-making}

Peace-making means that we seek the peaceful resolution of conflicts between individuals and groups.

Peaceful resolution of conflicts has three goals: to end hostilities, resolve the issues, and facilitate a restoration of relationships. Communities and nations are made up of weak and fallible human beings with an inherent tendency towards conflict. This is part of our human nature. It is, therefore, assumed that conflict is an ever-present possibility when individuals or communities take sovereignty into their own hands. It is fruitless, unproductive and naïve to ask: "How do we avoid conflict?" Instead, we should be asking: "How do we resolve conflict, by violence and swords or by peaceful means?". In a sense, we do not want to avoid conflict. Conflict is a healthy expression of wrestling with differences. Conflict is an opportunity to go deeper into a relationship.

The Christian perspective on peace-making: In the Sermon on the Mount, Jesus said: "Blessed are the peacemakers" (Matthew 5:9). Jesus taught and modelled a paradigm of non-violence. He taught about the avoidance of conflict in some situations (Matthew 5:38-42). It is interesting to note that Jesus teaches a dispute resolution process that involves negotiation and mediation (Matthew 18:15-18).

\subsection{Social justice}

Faith-based social justice means that we seek the common good through the transformation of a community's soul.

Social justice is the bedrock of any community or nation that seeks to be free of resentment and broken relationships. There can be no reconciliation without social justice. It is inherently tied to issues of privilege, land and economics. Faith-based social justice means that there is a moral grain to the universe established by God which governs human relationships and structures. It transcends political philosophy and asks the question: "What is the common good?". This would effect a transformation of a community's soul. 
The Christian perspective on social justice: Jesus displays all of this as he taught the moral absolutes of a just society in the Sermon on the Mount. He invited the rich young man to sell his possessions and give the proceeds to the poor. The lesson of respect taught to Simon the Pharisee about the sinful woman. His solidarity with the poor and outcasts. He was impartial of relationships with the powerful and powerless. Jesus had an integrated approach to politics and religion.

\subsection{Forgiveness}

Forgiveness means that we exercise forgiveness and repentance as individuals and communities in order to create the possibility of a better future together.

Forgiveness is the cornerstone to healing relationships between individuals and communities. It is a volitional act of giving up anger and resentment and extending pardon to an offending party. The act of forgiveness cannot be earned and is not deserved by the offending party. Forgiveness sets an individual, community or nation free from the burden of anger, pain, hatred, resentment, and the desire for revenge. It is powerful; it changes lives and transforms societies by releasing them from the wounds of the past.

The Christian perspective on forgiveness: Jesus' example from the cross: "Father, forgive them for they know not what they do". He extended the hand of forgiveness to Judas after betrayal. Simon Peter was taught that he must forgive $70 \times 7$, when he has been caused offence.

\subsection{Healing}

Healing means that we seek to heal the wounds of history by acknowledging suffering and injustice.

Healing wounded communities and nations is a spiritual and sociopolitical process that addresses painful historical memories with a view to acknowledgement, grieving, repentance, justice, and forgiveness. The collective identity is meant by God to create a sense of dignity and belonging for each of us, while creating a sense of "otherness" in terms of those who differ in race, ethnicity, culture, language, religion, or political ideology. The concept of collective identity has important implications in the interpretation and understanding of history. Often, people experience and internalise wounds not because they are a sign of personal offence, but because they arise out of their identification with a particular ethnic, social or religious group. In 2 Chronicles 7:14, God looks with compassion on our collective woundedness and desires to heal our land. 
The Christian perspective on healing historical wounds: Jesus saw that, in their woundedness, his own people Israel had distorted their call as the "chosen people" from one of being a blessing to the nations to one of exclusion and moral superiority. He also saw that in their woundedness, his own people had distorted the Abrahamic moral vision into a rigid moralism. The earliest followers of Jesus were Jewish who experienced rejection and persecution by their own people. Later they experienced rejection by the Gentile church.

\subsection{Sovereignty}

Acknowledging God's sovereignty is the bedrock of the faithbased perspective.

Orientation towards the divine is the heart of the faith-based worldview. A faith-based perspective assumes that acknowledging God's sovereignty is the dividing line between a sacred and secular world view. God has supreme authority over people, communities and nations. There is divine providence or intervention in human affairs.

The Christian perspective on sovereignty: Jesus bowed to God's will in the Garden of Gethsemane. He invited people to give their highest loyalty to God rather than to the state. His teaching was that the Kingdom of God is the basis of unity. He had an integrated focus of politics and religion.

\subsection{Atonement}

Atonement means that, ultimately, reconciliation is the process of finding peace with God.

To be human is to possess a spirituality; to experience a fundamental alienation which is at the core or essence of the human predicament; the experience of alienation from God, self and others. Atonement is the process of becoming a person of faith by finding peace with God that leads to the transformation of a person.

The Christian perspective on atonement: Jesus taught about forgiveness of $\sin$ and the gift of eternal life. He recognised human alienation from God as a fundamental problem (Cox 2007:2-10).

These core values represent comprehensive guidelines in working with and through the faith-based reconciliation process. A reading of these values presents an informed understanding of the Christian and the church. It would certainly help communities to employ these values as part of the process and journey to achieving reconciliation. 


\section{CONCLUSION}

From the discourse in this article, we can surmise that reconciliation would give impetus to reconstruction and development so that these could become missional paradigms that would pave the way to realistic and practical achievable goals.

Bosch helps us, to a large extent, understand the concepts of paradigms and apply these to missiology. The focus and examination of the theological reflection lends a deeper sense of introspection. By having these understandings, the work of the Triune God is vital for the missional paradigm of reconciliation. The important person of the Trinity is the work of the Holy Spirit in the Christian and the church through formation and empowerment. Reconciliation as praxis is inseparable from people and their contexts. This leads us to the core values.

These core values answer many questions and provide many solutions to issues raised in this article. The eight values with their characteristics and Christian perspectives would be an important set of values for a Christian, the community, society, the church group or all interested persons to work through. This will enable and equip such a group to become proactive in dealing with the issues and challenges of the day in post-1994 South Africa. It is hoped that this article will serve as a guiding document to implement the missional paradigms of reconciliation, reconstruction and development in order to build and bridge the many gaps in cultures, traditions, societies, communities, race groups, economic disparities, the poor, the disadvantaged and especially the spiritually poor in our beloved nation, South Africa (Pillay 2018:276).

\section{BIBLIOGRAPHY}

Bevans, S.B. \& Schroeder, R.P. 2004. Constants in Context. Maryknoll, New York. Orbis Books

BOSCH, D.J.

1991. Transforming mission. Maryknoll, NY: Orbis Books.

2000. A spirituality of the road. Eugene, OR: Wipf and Stock Publishers.

CAssidy, M.

1994. Behind South Africa's miracle. Christianity Today Vol.38. page 9.

Corder, C.K.

1997. The Reconstruction and Development Programme: Success or failure? Social Indicator Research, Vol. 41(1-3): 183-203. https://doi. org/10.1007/978-94-009-1479-7_8 
Cox, B.

2007. Faith-based reconciliation. Notes from a presentation given at the International Institute of Islamic Thought in Herndon, Virginia, on 2 February 2007, Virginia.

De Gruchy, J. (Ed.) \& Prozesky, M.

1990. Christianity in South Africa. Bergvlei: Southern Book Publishers.

GUDER, D.L.

1999. The incarnation and the church's witness. Eugene, OR: Wipf and Stock.

Hastings, A.

1971. Towards a spirituality of the road, mission and ministry. London: Sheed and Ward.

HAStings, R.

2012. Missional God, missional church. Downers Grove, ILL: InterVarsity Press.

JARDINE, V.

2008. The Truth and Reconciliation Commission: Success or failure? Unpublished MSc. dissertation in History. Pretoria: University of Pretoria.

KÄRKKÄINEN, V-M.

2002. An introduction to ecclesiology. Downers Grove, ILL: Intervarsity Press.

2013. Christ and reconciliation. Grand Rapids, MI: Wm B. Eerdmans.

KRITZinger, J.N.J. \& SAayman, W.

2011. David J Bosch, prophetic integrity and cruciform praxis. RSA Cluster Publications.

KUHN, T.S.

1996. The structure of scientific revolutions. $3^{\text {rd }}$ edition. Chicago: University of Chicago Press.

LAPSLEY, M.

2002. The healing of memories. Interview. The International Journal of Narrative Therapy and Community Work Vol.72:2.

Laudium Declaration

1990. The General Synod of the Reformed Church in Africa. A declaration of this church affirming its evangelical stance and approach to the issues in South Africa Acts 1990. Laudium, South Africa.

MANdELA, N.R.

1994. Long walk to freedom. Randburg, South Africa. MacDonald Purnell.

\section{News24}

2012. South Africa - Post 1994. 14 September. [Online.] Retrieved from: https:// www.news24.com/MyNews24/South-Africa-post-1994-20120914. [10 June 2018]. 
Niemandt, C.J.P.

2010. Five years of missional church: Reflections on missional ecclesiology. Missionalia 38(3):397-412.

2016. Transformative spirituality and missional leadership. Mission Studies 33(1):85-103. https://doi.org/10.1163/15733831-12341435

PilLAY, V.V.

2018. Reconciliation, reconstruction and development as paradigms for missiology in South Africa. Unpublished PhD. thesis. Pretoria: University of Pretoria.

SACHS, A.

2001. His name was Henry. In: W. James \& L. van de Vijver (eds), After the TRC: Reflections on truth and reconciliation in South Africa (Ohio: Ohio University Press) pp. 94-100.

SANGWENI, S. \& Balia, D

1999. Fighting corruption: South African perspectives. Pretoria. University of South Africa.

SCHREITER, R. J.

1992. Reconciliation - Mission and ministry in a changing social order. Maryknoll, NY: Orbis Books.

1998. The ministry of reconciliation - Spirituality and strategies. Maryknoll, NY: Orbis Books.

VolF, M.

1996. Exclusion and embrace. Nashville, TN: Abingdon Press.

1998. After our likeness. Grand Rapids, MI: Wm B. Eerdmans.

2006. The end of memory. Grand Rapids, MI: Wm B. Eerdmans.

WRIGHT, N.T.

2008. Surprised by hope. New York: Harper One.

Keywords

Reconciliation

Missional

Paradigm

Spiritual

South Africa
Trefwoorde

Versoening

Missionaal

Paradigma

Spiritueel

Suid-Afrika 